\title{
Boron-mediated aldol reactions of a methyl ketone containing a cyclic silicon protecting group
}

\section{Ellen Christine Polo and Luiz Carlos Dias}

\author{
Instituto de Química-UNICAMP, P. O. Box 6154, 13084-971, Campinas, SP-Brazil \\ *Idias@iqm.unicamp.br
}

Keywords: aldol reactions, boron enolate, 1,5-stereoinduction

\section{INTRODUCTION}

We have showed that aldol reactions involving boron enolates of methyl ketone containing a trans acetonide 1 with achiral aldehydes provided the corresponding aldol adducts with moderate to good levels of diastereoselectivity, favoring the 1,5-anti adduct. $^{1}$

Scheme 1. Aldol reactions of methyl ketone 1.

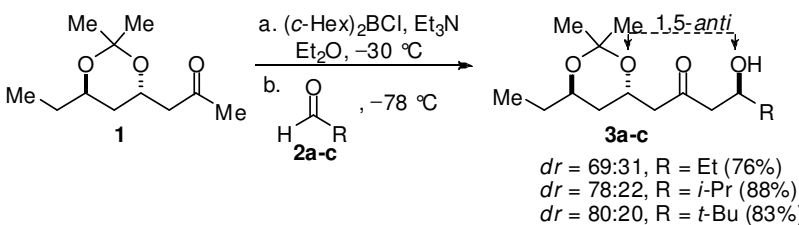

In this work we report the use of the boron enolate generated from methyl ketone $\mathbf{8}$, containing a cyclic silicon protecting group in a trans relationship in aldol reactions with achiral aldehydes. Our intention is to evaluate the steric and eletronic effect of the silicon protecting group in the selectivity of the reactions.

\section{RESULTS AND DISCUSSION}

Treatment of $\mathbf{4}$ with PMB-acetimidate followed by oxidation with PCC resulted in $\mathbf{5}$ (65\%, 2 steps). The aldol reaction between the boron enolate of methyl ketone 5 and aldehyde 2 a gave aldol adduct 6 (90\%, $d r>$ 95:05). Treatment of 6 with $\mathrm{Me}_{4} \mathrm{NHB}(\mathrm{OAc})_{3}$ (89\%, $d r>95: 05)$ followed by treatment with DTBS ditriflate resulted in 7 (97\%). The compound 7 was treated with DDQ (94\%) followed by Swern oxidation providing methyl ketone 8 (97\%) (Scheme 2$)$.

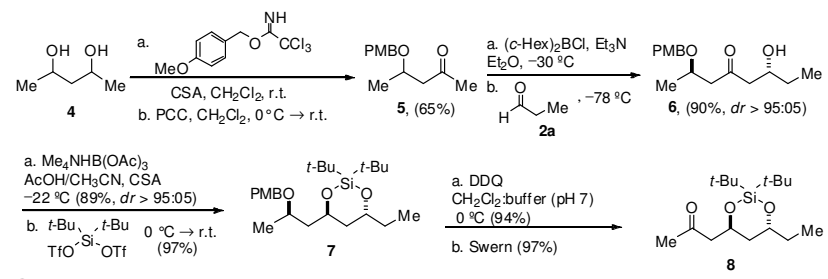

Scheme 2. Preparation of methyl ketone 8.

The aldol reactions of the methyl ketone 8 with aldehydes $2 \mathrm{a}-\mathrm{g}$ were investigated using $(c-\mathrm{Hex})_{2} \mathrm{BCl}$ and $\mathrm{Et}_{3} \mathrm{~N}$ in $\mathrm{Et}_{2} \mathrm{O}$, providing the 1,5-anti and 1,5-syn aldol adducts (10a-g and 11a-g) (Scheme 3, Table 1).

Scheme 3. Aldol reactions of methyl ketone 8 .

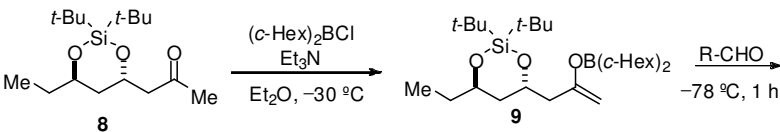

$$
\begin{aligned}
& \underbrace{t-\mathrm{Bu} u^{\prime, t-B u}-1,5-a n t i}_{10 \mathrm{a}-\mathrm{f}}
\end{aligned}
$$

\begin{tabular}{|c|c|c|c|}
\hline ent & Aldehyde (R) & $\begin{array}{c}d r^{\mathrm{a}} \\
(1,5-a n t i: 1,5-s y n)\end{array}$ & $\begin{array}{l}\text { Yield } \\
(\%)^{\text {b }}\end{array}$ \\
\hline 1 & Et (2a) & $88: 12$ & 88 \\
\hline 2 & $i-\operatorname{Pr}(2 \mathbf{b})$ & $83: 17$ & 92 \\
\hline 3 & $t-\mathrm{Bu}(2 \mathrm{c})$ & $72: 28$ & 84 \\
\hline 4 & $\mathrm{Ph}(\mathbf{2 d})$ & $66: 34$ & 88 \\
\hline 5 & $p-\mathrm{NO}_{2} \mathrm{C}_{6} \mathrm{H}_{4}(\mathbf{2 e})$ & $64: 36$ & 84 \\
\hline 6 & $p-\mathrm{OMeC}_{6} \mathrm{H}_{4}(\mathbf{2 f})$ & $67: 33$ & 89 \\
\hline $\begin{array}{l}\text { dia } \\
\text { bot } \\
\text { chr }\end{array}$ & $\begin{array}{l}\text { termined by }{ }^{1} \mathrm{H} \\
\text { meric mixture of } \\
\text { and syn isomer } \\
\text { aphy. }\end{array}$ & $\begin{array}{l}{ }^{13} \mathrm{C} \text { NMR analysis } \\
\text { ladducts. }{ }^{b} \text { Isolated } \\
\text { fter } \mathrm{SiO}_{2} \text { gel flash }\end{array}$ & $\begin{array}{l}\text { f the } \\
\text { Ids of } \\
\text { olumn }\end{array}$ \\
\hline
\end{tabular}

Table 1. Aldol reactions of methyl ketone 8

These results shown that aldol reactions involving the methyl ketone $\mathbf{8}$ provided the corresponding aldol adduct with moderate to good levels of diastereoselectivity favoring the 1,5-anti diastereoisomer.

The relative stereochemistry of aldol adducts $10 \mathrm{a}-\mathrm{f}$ was determined using the Kishi/Kobayashi method. ${ }^{2}$

\section{CONCLUSION}

We have demonstrated that the proper choice of protecting group is very important, as better selectivities were observed for less hindered aldehydes in the case of methyl ketone 8 (entries 13).

\section{ACKNOWLEDGEMENTS}

We are grateful to FAPESP, CNPq and CAPES.

\section{REFERENCES}

Polo, E. C. "Controle da estereoquímica remota 1,5 em adições de enolatos de boro de metilcetonas a aldeídos"; Dissertação de Mestrado, UNICAMP, 2011.

${ }^{2}$ Kobayashi, Y.; Tan, C.-H.; Kishi, Y. Helv. Chim. Acta 2000, 83, 2562.

$14^{\text {th }}$ Brazilian Meeting on Organic Synthesis - $14^{\text {th }}$ BMOS - September 01-05, 2011-Brasilia, Brazil 